\title{
THE COIMBINATION OF INQUIRY, LEARNING COMMUNITY, AND TOTAL PHYSICAL RESPONSE: A STUDY ON DEVELOPING ENGLISH LANGUAGE SKILL FOR ELEMENTARY SCHOOL STUDENTS
}

\author{
Sarinauli, Barep ${ }^{1}$, Herwanis, Delfia ${ }^{2}$, \\ STIKIP Muhammadiyah Takengon, IAIN Takengon
}

\begin{abstract}
The performance of the English language skill of the fifth graders of SD Negeri 1 Takengon was unsatisfactory (avarage score =34). The limited achievement was due to ineffective teaching and learning process. Therefore, it was suggested that a specific treatment of learning process needs to be well performed. This study aims at finding out if the combination of the Inquiry, Learning Community, and Total Physical Response is able to develop the performance of the students' English language skill. The study focuses on the students' performance to verbally respond to any simple instruction with acceptable actions within the context of classroom and school environment; and verbally express any expression of the following speech acts as: giving examples to do something, gesticulation, and giving directions (Departemen Pendidikan Nasional, 2006). In terms of the speaking skill, this study just concentrates on pronunciation and comprehension aspects. To achieve the goal of the study, an experimental approach with the one-group pre-test and post test design was used. The sample for the treatment was 20 students out of 58 students population which was selected randomly. The result shows that the performance of the students' English language skill in terms of comprehension and pronunciation was significantly improved (34 to 60). In conclusion, the research questions of this research are answerable - the combination of Inquiry, Learning Community, and Total Physical Response does lead to developing students' English ability in responding to simple instructions, and in expressing such speech acts as giving examples to do something, gesticulation, and giving directions. The hypothesis ( $\mathrm{Ha}$ ) of this research is then accepted as it provides a positive impact for the development of the students' English language ability, particulary in the area of focus of the study.
\end{abstract}

Keywords: Inquiry, Learning-community, Total Physical Response

\section{INTRODUCTION}

Speaking and listening are two important skills in communicative language performance. Brown, et.al as cited in Nunan (1999) found that prior experiences of the learner helps him/her to improve his/her performance as a speaker. Setiyadi (2006) states that children do a lot of listening before they learn to speak. Asher as cited in Richards \& Rodgers (1986) says that children develop listening competence before they develop the ability to speak. This idea is then developed by Mckay (2006) who asserts that the foundation of language learning 
is in the form of oral language, which consists of listening and speaking. Through oral language, children develop their literacy skills accompanying action.

Referring to curriculum from the Department of Education and Culture (Departemen Pendidikan Nasional, 2006), listening and speaking are given the highest priority to be learned by primary school students from grade 4 to grade 6 . The objectives of the instructions for English listening and speaking for grade 5 in the first semester are as follows:

The students have to be able to verbally respond to any simple instructions with acceptable actions within the classroom context and the school environment (Grade V, Semester 1: ref. SK/KD: 1/1.1

"To speak to accompany actions in an acceptable manner, which involves the following speech acts as: giving examples to do something, gesticulation, and giving directions (Grade V, Semester 1: ref. SK/KD: 2/2.1

Nevertheless, the results of a preliminary study (Author's survey, April 14$15,2013)$ showed that the students were not able to 'verbally respond to simple instructions and to demonstrate any expression of the speech acts mentioned above. In addition, the author found that the process of language learning in the classroom was ineffective due to an inappropriate use of the language learning strategies, methods and techniques. In order to solve such problems, the author planned to carry out an experiment on the application of the following methods viz: ', Inquiry, Learning Community and Total Physical Response combined together in the teaching process.

The main research question of this study is: "Does the combination of Inquiry, Learning Community, and Total Physical Response methods lead to developing the students' English ability?". This main question is broken down into the following sub-questions:

1. Does the combination of Inquiry, Learning Community, and Total Physical Response methods lead to developing the students' English ability in responding to simple instructions?

2. Does the combination of Inquiry, Learning Community, and Total Physical Response methods lead to developing the students' English ability in expressing such speech acts as giving examples to do something, gesticulation and giving directions?

Based on the stated research questions, the main research objective of this study is to find out if the combination of Inquiry, Learning Community, and Total Physical Response methods lead to developing the students' English ability. This main objective is expected to be answered through the following sub-objectives: 
1. To find out if the combination of Inquiry, Learning Community, and Total Physical Response methods leads to developing the students' English ability in responding to simple instructions.

2. To find out if the combination of Inquiry, Learning Community, and Total Physical Response methods leads to developing the students' English ability in expressing such speech acts as giving examples to do something, gesticulation and giving directions.

\section{METHODE}

This study is approached quantitatively by means of an experimental design of one group pretest-posttest design. According to Schreiber and Asner-Self (2011), the one group pretest-posttest design adds an observation of the group before the intervention. Cohen, Louis. Manion, Laurence Morrison (2005) explain that the extraneous variables which are outside the experimenter's control in one group pre-test $\mathrm{x}$ post-test designs threaten to invalidate the research effort. Therefore, it may be assumed that this kind of research method is in line with the main objective of this study, that is to find out if the combination of Inquiry, Learning Community, and Total Physical Response methods gives a positive impact for the student's Spoken English Performance. Or, in other words, if it may be said that such a combination of methods may positively develop the ability or performance of the students in Spoken English.

The population of this study is the fifth grade students of SD Negeri-1, Laut Tawar, Takengon. This school grade has 29 male students and 29 female student. So, the total number of population is 58 students, out of which $35 \%$ was then taken as sample. The sample of the study was taken by using a simple random sampling method which means that each member of the population under study has an equal chance of being selected (Cohen, Louis. Manion, Laurence Morrison, 2005). According to Schreiber and AsnerSelf (2011) simple random sampling occurs when all members of the population have the same probability of being selected. The author took both grades ( $\mathrm{Va}$ and $\mathrm{Vb}$ ) of the fifth year as the grade has two classes ( $\mathrm{Va}$ and $\mathrm{Vb}$ ). The author obtained an alphabetized list of all students in each grade, and then the author took the first 10 odd numbers of the $\mathrm{Va}$ class and the first 10 even numbers of the $\mathrm{Vb}$ class from a random number table. Next she went down the alphabetized lists and give consecutive numbers to each student and lastly she selected all the students according to the random numbers generated.

A research instrument, which plays an important role in research, is used as a tool to collect data (Arikunto, 2010). Similarly, Sugiyono (2009) explains in more comprehensive manner that a research instrument is a tool which is used to measure the natural phenomena and social phenomena that are being observed. In this research the data is collected by means of a test instrument. 
With regards to the quantitative design, the data is taken from pre-test and post-test scores from the sampled students before and after the treatment. Gronlund (1985) states, "an achievement test is a systematic procedure for measuring a representative sample performing a learning task".

In relation to the research design used in this research (one group pretest x post-test design), the author gave one pre-test and one post-test to measure the sample students listening and speaking abilities. In part one, the students focussed on learning vocabularies in terms of nouns and verbs. The teacher provided pictures as media for the teaching-learning process. The students got new vocabulary knowledge by discussion in groups. Furthermore, to reinforce the students' comprehension in listening, the teacher gave instructions verbally and the students listened to the instructions. And then in part two, the teacher measured the students performance in speaking ability through giving commands to the peer students or to the group. Both tests consisted of several topics related to the development of the ability to verbally respond to simple instructions with acceptable actions within the context of the classroom and the school environment. The materials for the test were adapted from internet sources and books. In addition, the author also adopted scoring systems from Mckay (2006) to assess the progress of the students after each treatment.

The author collected the data from the pre-tests and the post-tests. The pre-test was given before the treatment by way of an oral test. The pre-test included responding to instructions with appropriate actions for doing something, gesticulating, and giving directions. The treatment process was given for six sessions, each of the six sessions followed the same process, begining with learning vocabularies of nouns and simple verbs for doing something, gesticulating and giving directions.This was important for improving the students comprehension. To reinforce the instructions, commands were used to direct behaviour, reverse roles and produce action sequences. The post-test was given after the treatments using the same procedures as in the pre-test. All tests were scored by the author. The data of the study was gathered through "spoken language performance tests". These tests of listening and speaking abilities were conducted to test the students comprehension and performance related to simple instructions with acceptable actions within the context of the classroom and of the school environment and the ability to express in speech directions for doing something, viz: gesticulation and directions. Both tests were conducted after each session of the treatment, to record the students learning progress.

This study used simple statistical descriptive methods to display the data. Sugiyono (2009) states that there is no significance test for use with descriptive statistics. He adds that if the researcher does not intend to make a generalization so that there would then be no error in the generalization. The data of this study were analyzed and displayed using an Excel software program and an SPSS software program. 


\section{THEORY}

Some theories are provided to support the research. These theories are divided into several parts. the descriptions of Inquiry, Learning Community, and Total Physical Response methods.

Inquiry is the core of the CTL process. Galileo Education Work (as cited in Alberta (2004) states, "Inquiry is the dynamic process of being open to wonder and puzzlement and coming to know and understand the world". This knowledge is new to the students and may be used to answer a question, to develop a solution or to support a position or point of view. The knowledge is usually presented to others and may result in some sort of action.

Wilson \& Murdoch (2004) say, "The Inquiry approach to learning is based on the belief that students are powerful learners who must be actively engaged in the process of investigating, processing, organizing, filtering, refining and extending their knowledge within a topic. Referring to this statement, Vygotsky (1999) believed that children learn through interactions and dialogues when engaged in socially mediated activities.

Furthermore, Scardamalia \& Bereiter (as cited in (Bielaczyc \& Collins, 2013) explain that a Learning Community is a group of people who are actively engaged in a Learning Community. In recent years in America there has developed a "LearningCommunities" approach to education. In a Learning Community the goal is to advance the collective knowledge and in that way to support the growth of individual knowledge. In this regard, Garry (2002) states that a Learning Community exists when a group of people commit themselves to continual learning and to supporting others in continual learning. A Learning Community stimulates ongoing, collective inquiry into teaching and learning. It involves everyone in highly visible learning experiences who learn from each other, with each other, and for each other, who share the knowledge that is gained, the excitement and challenges that come with learning difficult material, and the benefits learning produces.

In a Learning Community approach the goal is to foster a culture of learning, where both individuals and the community as a whole are learning how to learn. Further more, Bielaczyc \& Collins., (2013) said that members of the community should share their individual efforts. The activities of a Learning Community must provide a means for:

a) both individual development and collaborative collection of knowledge;

b) sharing knowledge and skills amongst members of the community, and

c) making learning processes visible and articulated.

The goals of collegial forms of professional development are to encourage greater interaction between teachers, peer-based learning through mentoring, and sharing skills, experience and solutions to common problems. Thus, Farrell (2008) assert that the school might be viewed as a Learning Community.

A Learning Community approach tends to use a variety of learning activities, including individual and group research; class discussions; cross-age tutoring; working 
together to create artifacts or presentations that make public both what is learned and ways of learning; and collaborative problem solving where students take on particular roles toward a common end. For instance, social learning techniques such as co-operative learning and collaborative learning (Cohen, Louis. Manion, Laurence Morrison, 2005; Damon \& Phelps, 1989; Slavin, 1986 all cited in Bielaczyc \& Collins, 2013. Successful collaborative learning cannot be taken for granted and must be carefully planned and monitored (Farrell, 2008).

In addition, McMillan and Chavis (as cited in Bielaczyc \& Collins, 2013) state that there are four key factors that define a sense of community, namely: (i) membership influence, (ii) fulfillment of individual needs, (iii) shared events and (iv) emotional connections.

According to Garry (2002) the main principle supported in teaching using a Learning Community approach is developing others in creating an appropriate context for learning. It is context - the programs, procedures, beliefs, expectations, and habits that constitute the norm for a given school - that plays the largest role in determining whether professional development efforts will have an impact on that school. Garry then put forward that specific principles for such development must follow the steps below.

1. Provide time for collaboration in the school day and in the school year.

Providing time for teachers to work together does not require keeping students at home or an infusion of new resources.

2. Identify critical questions to guide the work of the collaboration teams. The impact of providing time for teachers to engage in collective inquiry will be determined to a great extent by the nature of the questions teachers are considering. Principals must help teams frame questions that focus on locally relevant critical issues of teaching and learning.

3. Ask teams to create products as a result of their collaboration. The best way to help teachers use their collaborative time productively is to ask them to produce and present artifacts in response to the critical questions they are considering. Examples might include statements of student outcomes by units of instruction, development of new units to address gaps between state standards and local curricula, creation of common assessments and rubrics, articulation of team protocols or norms to guide the interactions of team members, or formulation of improvement plans based on analysis of student achievement data.

4. Insist that teams identify and pursue specific (student) achievement goals. The driving force behind the effort to create a collaborative culture must be improved results. Principals can foster improved results when they ask teaching teams to identify and pursue specific, measurable student achievement goals. 
5. Provide teams with relevant data and information. When every teacher has access to information on their students' performance in meeting agreed upon standards for valid assessment in comparison to students of other teachers trying to achieve the same standards, both individual teachers and teams improve their effectiveness.

The Total Physical Response Method (TPR) is one of the methods developed by James Asher, a Professor of Psychology at San Jose University in California USA to aid learning language. This method attempts to encourage the students to listen and respond to spoken target language commands from the teachers. Asher cited in Richards \& Rodgers (2001) states that TPR is a language teaching method built around the coordination of speech and action. It attempts to teach language through physical (motor activity).

Furthermore, Larsen-Freeman (2011) called TPR a 'Natural Method', which means that the second language teaching and learning should reflect naturalistic processes of first language learning. She then explained that three central processes occur:

Firstly: Listening competence is developed before children develop their ability to talk. At the early stage of first language acquisition, children can understand complex utterances that they cannot spontaneously produce or imitate. Secondly: Comprehension: The student's ability in listening comprehension is acquired since the students are required to respond physically to spoken language in the form of commands.

Thirdly: Speech: When a foundation in listening and comprehension has been established, speech evolves naturally and effortlessly out of it.

Larsen-Freeman (1990) explained that the advocates of TPR believe that language learners should understand the target language before speaking. Language learners can learn through observing actions as well as by performing the actions themselves. By observing the actions and performing them they will understand the language they are learning. The meaning of words can be understood by making associations between the utterances they hear and the actions they are observing. The meaning of words will be internalized by performing the actions in accordance with the commands.

Larsen-Freeman (2011) further states that having fun makes language learners interested in learning (the foreign language). This is a primary principle of this method. The important principle in learning a foreign language is that the learners should have fun. In TPR the fun is provided through physical activities which are a means to reduce the stress people feel when studying a foreign language.

In addition, according to Larsen-Freeman (1990) TPR also deals with error correction. When a learner make an error, the teacher repeats the command while acting it out correctly so that the actions can be followed and the error corrected whilst still having fun. 


\section{FINDING AND DISCUSSION}

The data from the scores for each student ( ref. Attachment 5. the students' Pre-test and Post-test Scores), are summarised in the figures that follow:

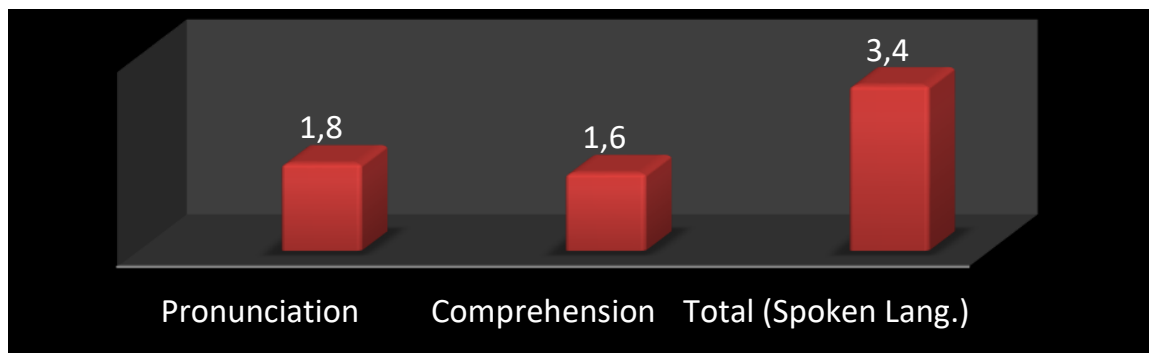

Figure 4.1.1

Students' Pretest

Scores for

Spoken

Component

Figure 4.1.1 shows that the students' average spoken language scores (focussed only on pronunciation and comprehension aspects) prior to the treatment were 1.8 and 1.6 respectively, total 3.4. This value indicated a relatively low performance. However, the values gradually increased during the treatment process as shown in the figure below:

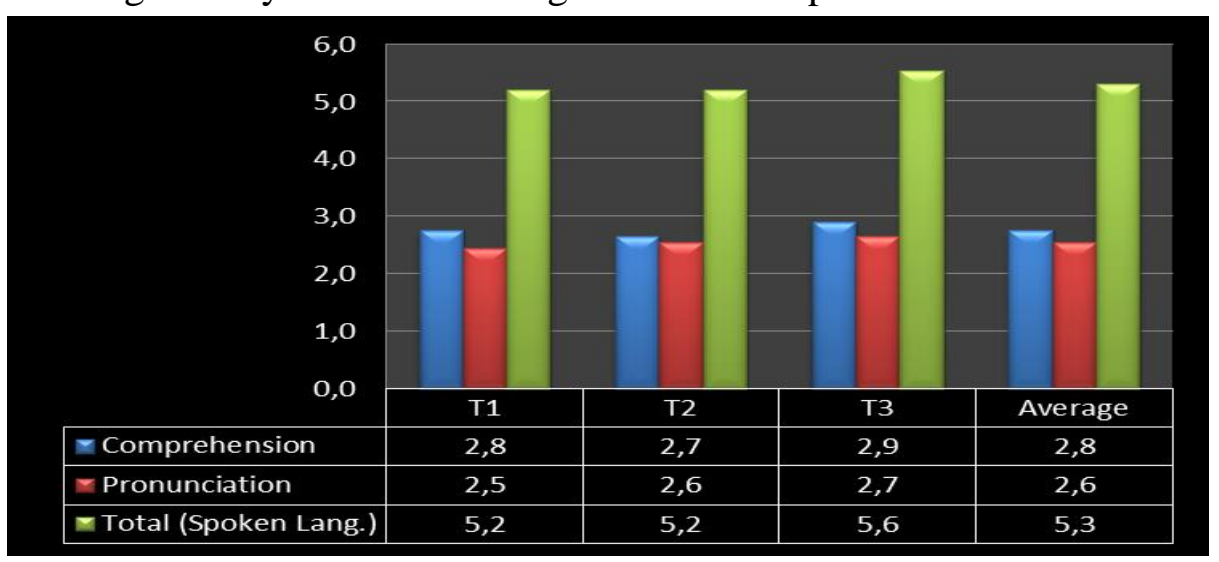

Figure 4.1.2 Students' progress achievement during treatment process

Figure 4.1.2 shows the results of the students's progress after each stage of treatment. Overall there were six meetings, two meetings per treatment. The tests were given at the end of the second meeting of each treatment. The students' achievement in both comprehension and pronunciation gradually increased from one treatment to the next. However, the comprehension results declined a little bit after the second treatment but rose again after the third treatment. The regression after the second treatment was due to using more difficult material. During the third treatment the students achievement went back to normal and increased by 0,1 point as they were now familiar with the new material. The average score achieved within the treatment process was 5.4 [comprehension (2.8); pronunciation (2.6)]. 


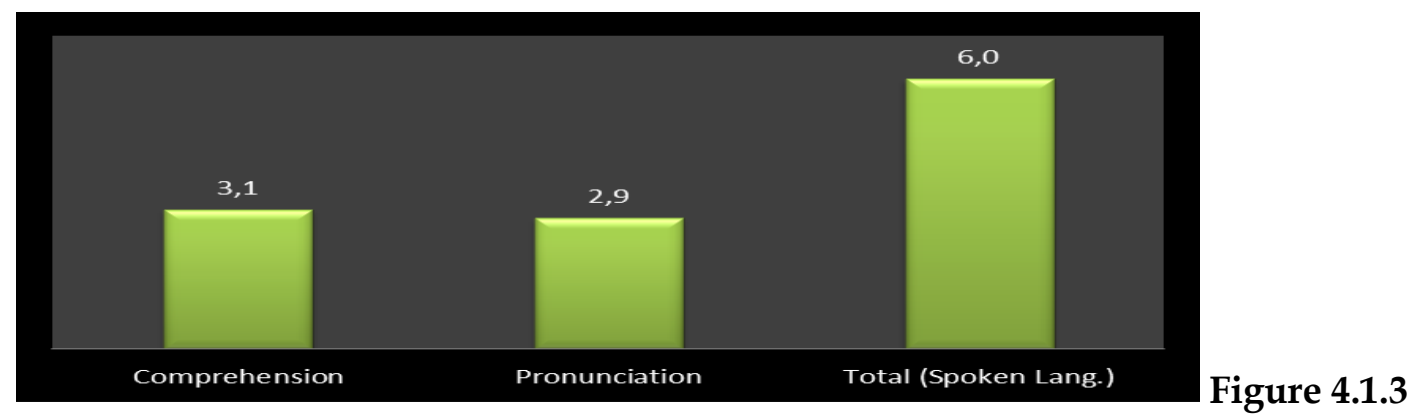

Students' Post-Test Scores for Spoken Language Component

Figure 4.1.3 represents the achievement scores from the post test, which was given as a formative assessment to see the end result of the treatment process after the sixth treatment for research.

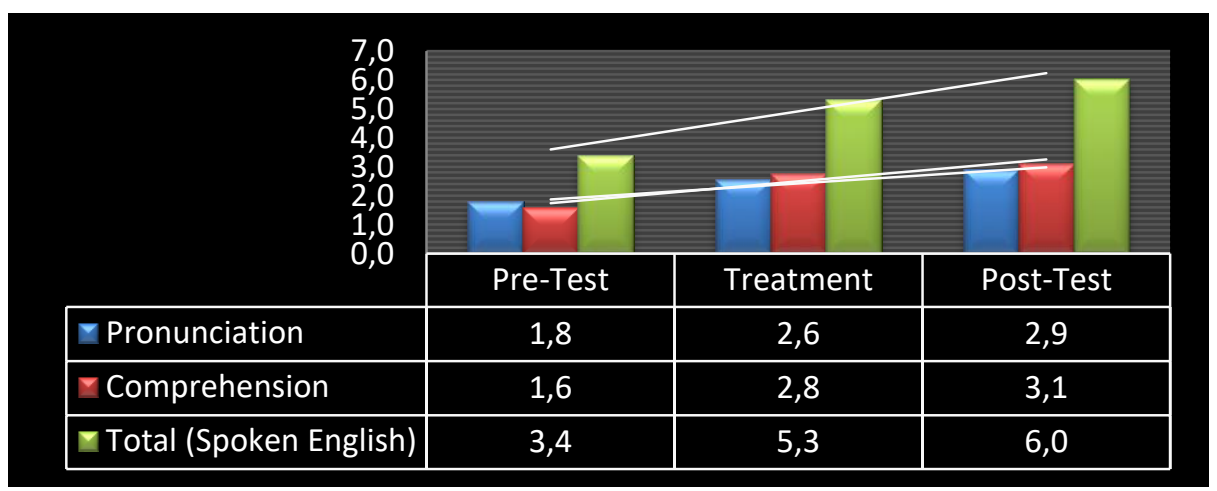

Figure 4.1.4 The comparative Score of Achievement among Pre-Test,

\section{Treatment, and Post Test}

While, Figure 4.1.4 signifies the comparison of scores achieved from the pre-test, treatment, and post-treatment tests. This clearly illustrates that the scores of the students' spoken language performance increased significantly after the teaching process was completed using the combination of Inquiry, Learning Community, and Total Physical Response processes.

After comparing the students' results from the pre-test with the post test results, it was found that their comprehension scores had increased significantly. Not only did the students know the meaning of the (new) instructions, they also used them appropriately which resulted in improved comprehension. The Total Physical Response methods improved the students listening comprehension. This is in line with the research findings of Brown as cited in Setiyadi (2006:125) who also claimed that memory is increased if it is stimulated through association with motor activities and the processes used to learn the first language. This was exactly what Larsen-Freeman (1986:118) explained viz: when commands are given to get students to perform an action, the actions make the meaning 
of the commands clear. The combination of Inquiry, Learning Community, and Total Physical Response processes not only helps students achieve cognitive and psychomotor activity goals but also increases their motivation and self-confidence because having fun makes language leaners interested in learning the foreign language. This is also a principle of the method.

This is supported by Larsen-Freeman (2006:128) who said that physical activities are able to reduce stress that some people feel when studying a foreign language. The research shows that the teaching process through the inquiry-based learning activity has made the students learn very actively and independetly. This finding corresponds with the statement of Kuhne as cited in Alberta (2004:1) who suggested that using inquirybased learning with students can help them become more creative, more positive, and more independent. Furthermore, the use of the professional Learning Communities method improved the students ability to get a deeper understanding of the subject matter by discussing and sharing with each other to solve their problems.

Pronunciation, on the other hand, seems to be the only speaking component that the students need to work on more in the future. Since the aspects of pronunciation are quite complex including the pronunciation of individual sounds, the placement of words and sentence stress and intonation; and considering that the students have never had to learn pronunciation exclusively before, they seemed to have a lot to catch on to produce a native-like pronunciation. Even though the students' pronunciation was already clear and intelligible, the articulation of individual sounds as well as the placement of word and sentence stress and intonation had yet to be perfected and achieved.

The Combination of Inquiry, Learning Community, and Total Physical Response methods was implemented without major difficulties. During the lesson activities at the six class meetings, the students showed positive attitudes to learning the new methods that they have never heard of before. They were actively engaged during the activities for learning the simple instructions and speech acts; they were involved in giving examples to do something, gesticulation and giving directions, plus responding and practicing good pronunciation and comprehension.

By using the combination of Inquiry, Learning Community, and Total Physical Response methods the author was able to integrate the teaching of topics like giving simple instructions and speech acts as well as giving examples to do something, gesticulation and giving directions. The combination of Inquiry, Learning Community, and Total Physical Response methods not only helped the students understand both the content and the language, but also helped them to perform the spoken language tasks.

The author found in this study that the sample students' speaking performance improved after six lessons. This was proved by the improved scores that the students achieved after receiving the combination of Inquiry, Learning Community, and Total Physical Response methods (pre-test average scores 3.4 increased to 6.0 post-test). The 
students comprehension in response to simple instructions and expression of speech acts plus pronunciation when performing the spoken language showed improvement compared to their performance before receiving the combination of Inquiry, Learning Community, and Total Physical Response methods.

Based on the data obtained and analyzed above, it is proved that the $\mathrm{H}_{\mathrm{a}}$ : The combination of Inquiry, Learning Community, and Total Physical Response methods provides a positive impact for the development of students' English ability both in responding to simple instructions, and expressing such speech acts as giving examples to do something, gesticulation and giving directions is accepted and the $\mathrm{H}_{\mathrm{o}}$ : is rejected.

In summary, it may be concluded that the application of the methods (combination of Inquiry, Learning Community, and Total Physical Response methods) to the elementary school students of SD Negeri 1 Takengon has imparted a constructive impression to the development of an instructional strategy of learning English for young learners.

\section{CONCLUSION}

Based on the test scores, it was found that the students' spoken language performance increased after being given the combination of Inquiry, Learning Community, Total Physical Response methods (Average score pretest 3.4 increased to 6.0 post-test). Most of the students, 18 all together, improved their pronunciation, only two students did not show any improvement; whilst in comprehension nearly all of the 20 students showed improvement; three students, who scored well in the pre-test, got the same score in the post-test.

Second, the combination of Inquiry, Learning Community, Total Physical Response methods was successfully implemented in an elementary classroom environment to improve the students' English performance. This indicates that classroom instruction based on a combination of methods especially combining Inquiry, Learning Community, Total Physical Response methods can produce better performance of English.

Third, the combination of Inquiry, Learning Community, Total Physical Response methods successfully improved the students' comprehension and pronunciation. Thus the combination of Inquiry, Learning Community, Total Physical Response methods has been shown to be a successfull combination in this study and could result in success in future Speaking English lessons.

Fourth, the application of the methods has developed not only the students' teamwork and responsibility in mastering learning materials for spoken language performance, but also improved their self-confidence and awareness of being in control of their own learning and hence they were able to perform well.

In conclusion, the result of research shows that the application of the combination of Inquiry, Learning Community, and Total Physical Response does lead to developing English ability for the elementary level of students both in terms of responding to simple 
instructions and in expressing certain speech acts (giving examples to do something, gesticulation and giving directios). This finding confirms that the research questions of this study are proved. In addition, the status of hypothesis has now changed from 'hypothetical' to 'thesa', which means that the application of the combination of Inquiry, Learning Community, and Total Physical Response provides positive impact to the development of the English ability of elementary school students.

\section{REFERENCES}

Alberta. (2004). Focus oLearning, Imn Inquiry.

Arikunto, S. (2010). Prosedure Penelitian : suatu Pendekatan Praktik (Edisi Revi). Jakarta: Rineka Cipta.

Bielaczyc, K., \& Collins, A. (2013). Learning communities in classrooms: A reconceptualization of educational practice. Instructional-Design Theories and Models: A New Paradigm of Instructional Theory, 2, 269-292. https://doi.org/10.4324/9781410603784-18

Cohen, Louis. Manion, Laurence Morrison, K. (2005). Research Methods in Education (Fifth Edit). London: Routledge, Falmer, Taylor and Francis.

Damon, W., \& Phelps, E. (1989). Critical distinctions among three approaches to peer education. International Journal of Educational Research, 13(1), 9-19. https://doi.org/10.1016/0883-0355(89)90013-X

Departemen Pendidikan Nasional. (2006). Standar Kompetensi dan Kompetensi Dasar: Panduan Pengembangan Sillabus per Mata Pelajaran, Rencana Pelaksanaan Pembelajaran (RPP), dan Model Kurikulum Tingkat Satuan Pendidikan (KTSP). Jakarta: PT. Bina Tama Raya.

Farrell, T. S. C. (2008). Brief reflective practice in the professional development of teachers of adult English language learners. CAELA Network, (October), 1-4.

Garry, B. G. (2002a). Building and Sustaining Learning Communities: A Professional Development Resources Guide. Lexington. Partnership for Kentucky Schools Gronlund, Norman E.1993. How to Make Achievement Tests and Assessments (Fifth Edit). USA: Allyn and Bacon.

Garry, B. G. (2002b). Building and Sustaining Learning Communities: A Professional Development Resources Guide. Lexington. Partnership for Kentucky Schools Gronlund, Norman E.1993. How to Make Achievement Tests and Assessments . (Fifth Edit). USA: Allyn and Bacon. 
Gronlund, N. E. (1985). Measurement and evaluation in teaching (5th ed). Boston: Allyn and Bacon.

Larsen-Freeman, D. (1990). Language Teaching Methods: Teacher's Handbookfor the Video Series.

Larsen-Freeman, D. (2011). Technique \& Principles in Language Teaching. 318.

Mckay, P. (2006). Assessing Young Language Learners: Cambridge Language Assessment Series : UK: Cambridge University Press.

Nunan, D. (1999). Second Language Teaching and Learning. Boston: Heinle and Heinle.

Richards \& Rodgers. (1986). Approaches \& methods in language teaching: preparing the terrain. Approaches and Language Teaching, 170.

Richards, J. C., \& Rodgers, T. S. (2001). Approaches and Methods in Language Teaching. https://doi.org/10.1017/CBO9780511667305

Schreiber James B and Asner-Self, K. (2011). Educational Research: The Interrelationship of Questions, Sampling, Design and Analysis. United States of America: John Willey \& Sons.

Setiyadi, A. B. (2006). Teaching English as a Foreign Language. Yogyakarta: Penerbit Graha Ilmu.

Sugiyono. (2009). Metode Penelitian Pendidikan: Pendekatan Kuantitatif, Kualitatif, dan R\&D. Bandung: Alfabeta Bandung.

Vygotsky, L. S. (1999). Vygotsky 's Sociocultural Theory. Education Psychology for Learning, (2007), 26925. https://doi.org/10.1007/978-94-007-4065-5

Wilson, J., \& Murdoch, K. (2004). What is Inquiry Learning? Challenges for Teachers Implementing Inquiry. 1-8. 